\title{
História, Memória e Teologia: A tensão histórica e escatológica no Cancioneiro Popular das CEBs
}

\author{
Orientador: Luís Corrêa Lima
}

Mestrando: João Pedro Augusto Alves de Holanda

Área de Concentração: Teologia Sistemático-Pastoral

Linha de Pesquisa: Religião e Modernidade

Projeto de Pesquisa: História da Igreja e Modernidade: Permanências e Mudanças

A história, a memória e a teologia, preservada nos versos das canções produzidas pelas Comunidades Eclesiais de Base, são de suma importância para a História Eclesiástica. Os cantos do Cancioneiro Popular das CEBs constituem uma realidade presente na Igreja do Brasil. Era preciso adentrar a história desses cantos, revisitar suas memórias e analisar sua teologia para compreender melhor o valor que a CNBB atribui a estas canções. Esta dissertação objetiva analisar a construção da história, memória e teologia das canções do Cancioneiro Popular das CEBs. Objetiva analisar de maneira histórico-teológico a arte produzida pelos adeptos da Teologia da Libertação. Essas Canções de Esperança são um patrimônio vivo, que trazem em si o legado das lutas, vitórias e derrotas dos que a todo custo tentaram denunciar as injustiças e anunciar que o reino já está entre nós. As canções cebianas trazem em si uma antecipação escatológica de uma realidade "já" existente, porém, "ainda não" completada. Nas canções das CEBs são facilmente encontradas traços da Teologia da Práxis e da Teologia da Esperança, por isso, a teologia apresentada nestas canções provocam uma inquietação no homem que por causa de Cristo não se contenta com a realidade dada, deseja contradizê-la. Percebe-se, assim, que a tensão faz parte da vida cristã - apesar da esperança - e que toda a vida do homem está embebida da índole escatológica que deve ser vivida à luz da Esperança maior que se faz realidade “já" aqui, mas "ainda não" é aqui. Logo, essas canções fomentam a luta para que a realidade do "já" seja uma antecipação do "ainda não".

Palavras-chave: Tensão “já" e "ainda não”. Teologia da Práxis. Teologia da Esperança. 